\title{
HISPANIC PLACE NAMES OF JAMAICA: DIACHRONIC ASPECT
}

\author{
Irina A. Martynenko \\ Kutafin Moscow State Law University (MSAL), Moscow, Russia
}

\begin{abstract}
Spanish components in the toponymy of the state of Jamaica are semiotic markers of the Spanish culture in this region that are presented in peculiar cartographic forms of the Spanish language. The variety of forms of geographical names under study indicates the clash of civilizations, points to heterogeneity of language contacts and multitude of lexical resources of the local toponymic system. The article presents the results of an integrated linguistic analysis with the aim to describe Jamaican Spanish toponymic units and examine their current functioning with consideration of language contacts with English and other languages. Over 300 place names of the region were identified and analyzed at the micro- and macrotoponymic levels. Using the method of thorough sampling, the units with a Spanish component, amounting to a fourth of all the studied toponyms, were identified, their structure and etymology were described. Hypotheses about the origin of some Hispanic geographical names of the region are put forward and verified. Numerous examples of Hispanic place names reflect the historical processes that influenced the birth of toponymic nominations in this multinational region from the times of Columbus to the present day. The structural and chronological criteria were taken into consideration while developing a classification of Hispanic place names of Jamaica.
\end{abstract}

Key words: Jamaica, toponymy, place name, Spanish, English, linguoculturology.

Citation. Martynenko I.A. Hispanic Place Names of Jamaica: Diachronic Aspect. Vestnik Volgogradskogo gosudarstvennogo universiteta. Seriya 2. Yazykoznanie [Science Journal of Volgograd State University. Linguistics], 2020, vol. 19, no. 6, pp. 123-133. (in Russian). DOI: https://doi.org/10.15688/jvolsu2.2020.6.9

УДК $811.134 .2+811.111^{\prime} 373.21$

Дата поступления статьи: 01.08.2019

ББК $81.40-316$

Дата принятия статьи: 14.09.2020

\section{ИСПАНОЯЗЫЧНАЯ ТОПОНИМИЯ ЯМАЙКИ: ДИАХРОНИЧЕСКИЙ АСПЕКТ}

\section{Ирина Анатольевна Мартыненко}

Московский государственный юридический университет им. О.Е. Кутафина (МГЮА), г. Москва, Россия

Аннотация. Испаноязычные компоненты в топонимии государства Ямайка являются своеобразной картографической формой существования испанского языка, семиотическим маркером присутствия испанской культуры в данном регионе. Обнаруженная гетерогенность форм географических названий указывает на столкновение цивилизаций, неоднородность языковых контактов и богатство лексических ресурсов локальной топонимической системы. В статье представлены результаты комплексного лингвистического изучения испаноязычных топонимических единиц Ямайки и их современного функционирования с учетом языковых контактов с английским и другими языками. Работа построена на материале картографического анализа: выявлено и охарактеризовано более 300 топонимов региона на микро- и макротопонимическом уровнях, из них методом сплошной выборки выделены единицы с испанским компонентом (четвертая часть ¿ от всех исследуемых топонимов). Описана структура и этимология испаноязычных топонимических наименований. Автором выдвинуты и верифицированы гипотезы о происхождении некоторых испаноязычных географических имен, существующих на острове, которое отражает исторические процессы, повлиявшие на присвоение топонимических номинаций в данном полинациональном регионе со времен Колумба до наших дней. Предложена классификация испаноязычных топонимов Ямайки с учетом структурного и хронологического критериев.

Ключевые слова: Ямайка, топонимика, топоним, испанский язык, английский язык, лингвокультурология. 
Цитирование. Мартыненко И. А. Испаноязычная топонимия Ямайки: диахронический аспект // Вестник Волгоградского государственного университета. Серия 2, Языкознание. - 2020. - T. 19, № 6. - C. 123-133. - DOI: https://doi.org/10.15688/jvolsu2.2020.6.9

\section{Введение}

Топонимические единицы занимают особое место в лексической системе любого языка. Являясь хранителями «зашифрованных» сведений о прошлом региона, они не только обозначают географические объекты, но и содержат культурно-историческую информацию, указывающую на этническую принадлежность народа, населяющего или населявшего ту или иную территорию. Изучение динамики отдельного топонимикона в диахроническом аспекте позволяет определить типичные для местного социума принципы географических номинаций, тенденции взаимодействия двух и более лингвокультур, охарактеризовать процессы языковой конвергенции в рамках одного топопространства.

Топонимика Ямайки, столетиями формировавшаяся в полинациональных условиях, представляет собой гетерогенный корпус географических имен и требует особого внимания специалистов по ономастике и теории языковых контактов. Девиз государства Out of Many, One People («Из многих людей - единый народ») находит свое отражение и в топонимической системе, строящейся на «разновозрастных» единицах из нескольких языков.

Ономастические исследования географической номенклатуры государства Ямайка ведутся с начала XX в., в основном зарубежными специалистами (см., например: [Beek, 1975; Cundall, 1909; Cundall, Pietersz, 1919; Higman, Hudson, 2009; Padrón, 1952; Sibley, 1978]). Ученых привлекают номинации, отражающие столкновение лингвокультур на протяжении столетий, этимология и современное функционирование местных географических названий. Однако топонимикон региона на данный момент не может считаться полностью изученным: этимология многих единиц не выявлена, мало исследованы современные узуальные нормы в отношении топонимических единиц испанского происхождения, топонимические словари Ямайки не представляют современного состояния системы топонимов (имеющиеся лексикографические источники датированы началом XX в.).
Испанские компоненты в топонимии государства Ямайка - своеобразная картографическая форма существования испанского языка, семиотический маркер присутствия испанской культуры в данном регионе. Однако и этот пласт ямайской топонимической системы остается недостаточно изученным. В данной статье представлены результаты комплексного лингвистического анализа испаноязычных топонимических единиц Ямайки на фоне их функционирования в современном полиязычном топонимиконе острова.

\section{Материал и методы исследования}

Изучение испаноязычных единиц в топонимии региона (их структурная систематизация, установление прагматических характеристик) осуществляется с применением методов ономастики и лингвокультурологии, их современное состояние описано через призму контактов испанского языка с английским и другими языками, бытующими на острове.

Исследование проведено на материале картографического анализа Ямайки. Нами выявлено и проанализировано более 300 топонимов региона, из которых методом сплошной выборки выделены единицы с испанским компонентом (75 единиц). Мы охватили географическую номенклатуру страны как на макро-, так и на микротопонимическом уровне: нами изучены названия островов, графств, округов, городов, деревень, гор, рек, холмов, заливов, улиц, отелей.

\section{Результаты и обсуждение}

\section{Причины полиязычности топонимикона Ямайки}

До прихода испанцев Ямайку населяли индейские племена араваков, принадлежавшие к различным языковым группам. Самым многочисленным было племя таино, численность которого достигала 60 тысяч человек [Степанов, 1980, с. 18]. За период испанского господства индейцы на Ямайке исчезли пол- 
ностью: к 1655 г. не осталось ни одного автохтона [Cassidy, 1988, p. 155]. Начав колонизацию острова, испанцы не сохранили индейских географических наименований: названия, данные таино, исчезли и теперь неизвестны. Однако само название острова происходит от слова Xатауса, что на языке таино буквально означает «остров родников» или «земля ручьев» [Степанов, 1980, с. 17]. Память о первых хозяевах острова хранят эргонимы Arawak Hotel (до переименования в Jamaica Hilton Hotel) и Arawak Inn Hotel.

Начало так называемого «испанского периода» в регионе датируется 4 мая 1494 г., когда Колумб во время своего второго путешествия в Новый Свет открыл остров и провозгласил его владением испанских католических королей Фердинанда и Изабеллы. В 1506 г. Ямайка официально была отдана испанской короной семье Колумба, но в дальнейшем ее представители отказались от владения в обмен на титул и пожизненную пенсию [Степанов, 1980, с. 18]. Тем не менее в 1508 г. началась колонизация острова испанцами. Им управлял губернатор, назначаемый королем. Ямайка была включена в состав генералкапитанства Кубы. Испанские поселенцы захватили обрабатываемые земли и подчинили индейцев, заставив их работать на себя.

В 1655-1660 г. английские мореплаватели начали свою завоевательную кампанию и довели ее до успешного завершения. В этот период испаноязычные и англоязычные топонимы сосуществовали на Ямайке, однако их соседство было крайне напряженным.

Окончанием эры господства испанцев можно считать 1660 г., когда, будучи изгнанным с острова англичанами, последний испанский губернатор отплыл на Кубу из бухты, которая впоследствии была названа Runaway Bay (англ. «бухта побега»). Здесь необходимо отметить, что испанцы освободили своих верных негритянских рабов, которые, поднявшись на холмы, развязали партизанскую войну против англичан. Это стало началом движения марунов, которые позже расширили свои поселения на холмах, сопротивлялись англичанам до конца XVIII в. и дали африканские и креольские наименования географическим объектам на Ямайке (об этом см.: [Cassidy, 1988, p. 156]).
В 1670 г. Мадридский договор признал Ямайку английским владением (БРЭ).

Ямайский национальный вариант английского языка имеет черты, отличающие его от ямайского креольского языка, на котором предпочитают говорить местные жители (о становлении и развитии ямайского национального варианта английского языка см., например: [Бушманов, Митчелл, 2017; Дроздов, 2017; Тарасова, 2006; и др.]).

Как показано А. Сэнд, ямайский креольский язык развился в XVII в., когда рабам из Западной, Восточной и Центральной Африки приходилось учиться понимать друг друга и рабовладельцев, которые в большинстве своем говорили на разных вариантах английского языка: британском, шотландском и ирландском [Sand, 1999, p. 24].

Ямайский креольский язык носители языка называют патуа (Patois / Patwa), причиной чего, согласно одной из версий, является влияние французского языка, в котором данное слово имеет значение «местный говор / диалект». Патуа - контактный язык на английской основе, содержащий также слова и правила, пришедшие из ирландского, французского и различных африканских языков. При этом, по наблюдениям И.В. Лесниковской, произношение ямайцев имеет значительное сходство с произношением в южной Ирландии [Лесниковская, 2013].

Указанные особенности нашли свое отражение в ямайском топонимиконе, в частности в ойконимических именованиях Gimme-Bit и Me No Sen You No Come.

Современный топонимический корпус страны в целом англоязычный, с вкраплением испаноязычных единиц и формантов, а также наименований из других языков. Несмотря на то что испанский язык не используется на острове ни как официальный, ни как разговорный (государственный язык Ямайки - английский), по нашим оценкам на отыспанские географические наименования приходится сегодня около $25 \%$ топонимов острова.

\section{Классификация испаноязычной топонимической лексики Ямайки}

Испаноязычныетопонимы Ямайки неоднородны по времени их появления: одни из них 
возникли в период колонизации, другие-в постколониальный период.

Топонимы, возникшие в период колонизации Ямайки, можно разделить на 2 группы: сохранившиеся и не сохранившиеся в топонимиконе Ямайки.

1. Сохранившиеся испаноязычные mопонимы неоднородны, среди них можно выделить оригинальные испанские наименования и трансформированные топонимические единицы.

1.1. Оригинальные испанские топони-

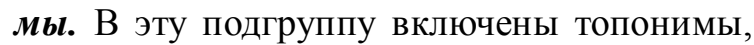
полностью сохранившие испаноязычный облик, и топонимы, сохранившие испаноязычные элементы.

Некоторые ранние испанские географические имена Ямайки столетиями продолжают указываться на картах без изменений. Это широко известные с давних времен названия объектов, важных для навигации и судоходства, а именно рек: Rio Grande, Rio Cobre, Rio Pedro, Rio Doro (производное от Rio de Oro), Rio Magno.

Река Rio Nuevo также сохранила свое исконное название. В близлежащем районе в 1658 г. произошло крупнейшее в ямайской истории сражение между испанскими и английскими завоевателями.

Rio Minho - самая длинная река на Ямайке протяженностью 92,8 км. Свое название она берет от испано-португальской реки Mico, истоки которой находятся в Кантабрийских горах. Далее река протекает по холмистой местности автономного сообщества Галисия. Последние 80 км до впадения в Атлантический океан Мico являются границей Испании и Португалии. Примечательно, что ямайский дублет графически повторяет португальский вариант - Minho (ср. исп. Mico).

Сохранились и испанские названия других водных объектов.

Гавань Rio Buеno является самой глубокой на Ямайке. Возможно, это одна из причин, по которой Колумб бросил в ней якорь во время своего первого посещения острова. Небольшой приморский поселок Rio Bueno обязан своим существованием одноименной реке и гавани. Он образован в первые годы английской колонизации как место остановки для мореплавателей и наземных путников; традиционно здесь размещались таверны и гостиницы.

Как видно из приведенных примеров, англичане сохранили опорный компонент Rio в испанских наименованиях рек: Rio Cobre, Rio Minho, Rio Grande, Rio Nuevo, Rio Bueno; однако современное произношение этих номинаций не соответствует испаноязычной норме: [raio njuvou], [raio bjunou]. Следует также отметить ассимиляцию топоформанта Rio без графического значка ударения. На Ямайке данная тенденция развивалась по аналогии с другими регионами, где англо- и франкоязычные колонизаторы принимали топосистему после испанских поселенцев (об этом см.: [Мартыненко, 2018, с. 57; Мартыненко, Ильина, Куприянова, 2019; Чеснокова, Мартыненко, 2019]).

Большинство испаноязычных имен сохранилось в гибридизированном варианте. Типичные ямайские топонимы-гибриды образованы посредством формантов Pen и Gully. На Ямайке Pen обозначает скотоводческое хозяйство, ферму [Higman, Hudson, 2009, p. 7], a Gully - водосток: Cedar Grove Pen, Cedar Gully, Liguanea Pen, Mount Diablo Gully.

Ввиду того, что Ямайка - морское государство, английский формант Port является основой для многих англо-испанских гибридов. Например, деревня Port Esquivel названа в честь первого испанского губернатора острова Хуана де Эскивела (Juan de Esquivel).

Испаноязычные элементы Sierra или Montaca / Montana не сохранились в оронимах, они были вытеснены англоязычными топоформантами Mount и Mountain(-s): Mount Diablo, Juan de Bolas Mountain, Mocho Mountains. Вытеснены были и другие испаноязычные элементы. Rio заменялся на River: Cabaritta River, Montego River, Morant River, Negro River. Кроме того, англичане старательно переводили Punto в Point, a Bahia - в Bay. Так, бухты Punto de Morante и Bahia de Morante (названные в честь выдающейся испанской семьи) сохранили испанский компонент, но трасформировались в Morant Point и Morant Bay.

Liguanea - наименование одной из девяти животноводческих ферм (hatos), созданных во времена заселения острова испанцами. Только она сохранила свое первоначальное название. Как пишет У. Рэндел, название 
ранчо Liguanea - это испанизированная форма слова iguana / игуана, что в переводе с языка араваков означает «ящерица». Изображение ящерицы было символом Лигуанеа на протяжении более ста лет, и неслучайно: в этой области игуаны водились в изобилии. Топоним Liguanea претерпел несколько трансформаций в написании и произношении. Задокументированы трудности адаптации названия ранними английскими поселенцами: на первой английской карте написано Legonee. Зафиксированы и другие промежуточные формы: Lygonee, Ligonia, Liguiania, Ligonea, Liguany и Liguanee [Randel, 1960, p. 27].

В 1494 г., когда Христофор Колумб впервые посетил остров, он назвал залив, известный сейчас как Montego Bay, заливом Golfo de Buen Tieтро (исп. «Залив хорошей погоды»). Основная версия происхождения названия Montego Bay - от испанского слова manteca («сало»), предположительно потому, что в период пребывания на острове испанцев это был порт, куда экспортировалось сало, кожа и говядина. По другой версии, множество свиней были забиты здесь и отправлены в Картахену (Испания). Существует также мнение, что залив был назван в честь колониста Монтего Саламанки (Montego Salamanca).

Miranda Hill - наименование холмов, которые вместе с побережьем являются одним из самых живописных мест залива Montego Bay. Здесь находится много великолепных комфортабельных отелей, предлагающих гостям сервис высокого уровня. Холмы названы в честь бывшего испанского губернатора Алонсо де Миранда (Alonzo de Miranda).

Ocho Rios (исп. «восемь рек») - наименование города в округе St. Ann. Ученые настаивают на том, что название является измененным испанским словом chorreras, которое обозначает многочисленные водяные потоки [Higman, Hudson, 2009, p. 29; Padrón, 2003, p. 353; Randel, 1960, p. 28]. Б.В. Хигмэн и Б.Дж. Хадсон приводят сделанное еще в 1890 г. наблюдение Э.М. Бейкона (Edgar Mayhew Bacon) и Ю.М Аарона (Eugene Murray Aaron), которые заметили, что $c h$ в Ocho произносится местными жителями мягко, в угоду испанскому происхождению слова. Оно звучало как Chereras «Залив водопа- дов» - название настолько же описательное, насколько поэтичное. Перевод «восемь рек» неточен по отношению ко множеству ручьев, которые, вспениваясь, устремляются по склонам и охлаждают свои «кипящие маленькие тела» в море [Higman, Hudson, 2009, p. 29]. Ocho ríos в переводе с испанского действительно означает «восемь рек», в то время как значение «водопад» в испанском языке, как правило, выражается лексемами cascada, catarata или salto de agua. Chorrera же имеет несколько значений: «сток», «след, оставшийся от стока воды», «водопад» (DRAE). Поэтому мы полагаем, что искажение испанского chorreras могло иметь место: слово указывает на местные водопады, часть из которых впадает в море.

Наименование горы Mount Diablo связано с ее первоначальным испанским названием Diablo Monte (исп. «гора дьявола»), наводящим на мысль об опасном пути, пролегавшем через эту местность.

Наименование пляжа Great Pedro Bay сохраняет испаноязычный элемент. В источниках нами не было обнаружено версий о происхождении метонимической цепочки с компонентом Pedro. Мы считаем, что протагонистом мог быть один из губернаторов Ямайки: Педро де Масуэло (Pedro de Mazuelo), 1523-1526 гг.; Педро Кано (Pedro Сano), дважды вступавший в должность - в 1539 и 1558 гг.; Педро Кабальеро (Pedro Caballero), 1646-1650 годы. Данный антропотопоним может быть обязан своим происхождением и имени Педро Алонсо Ниньо (Pedro Alonso Nico) - спутника Колумба.

Гибридное наименование пруда Alligator Pond содержит компонент Alligator, восходящий к испанскому el lagarto («ящер»).

Название горного хребта Mocho Mountains содержит испаноязычный компонент тосhо («тупой»).

Наименование горы Juan de Bolas Mountain дано в честь первого предводителя ямайских марунов (беглых негров-рабов). НаЯмайке существует праздник - День марунов или маронов (англ. maroon). Он отмечается 6 января - в день рождения капитана Куджо (Cudjoe), маруна, одержавшего победу над английской армией в 1730-х гг. [Биография Куджо]. Как отмечает Ю.С. Степанов, 
рабов на Ямайку стали ввозить еще испанцы с 1513 г. [Степанов, 1980, с. 21], но работорговля в регионе достигла своего пика после захвата острова англичанами. Английские колонисты, окончательно укрепившись на Ямайке, по словам А.Д. Дридзо, превратили остров в огромную сахарную плантацию, где нещадно эксплуатировали сотни тысяч африканских невольников [Дридзо, 1971, с. 75].

\section{2. Трансформированные испаноязыч-}

ные названия. Испаноязычные топонимические единицы, сохранившиеся в измененных или усеченных формах, немногочисленны. В peзультате трансформаций испанский компонент порой трудно определяется.

Так, например, ойконим Yallahs имеет испанское происхождение. В период испанского господства одна ферма (hato) на юговостоке Ямайки получила свое название в честь известной в регионе испанской семьи Ayala (Айала). По наблюдениям У. Рэндела, в 1661 г. появились две формы: Yallah и Yallowes. Одна из них (Yallah) зафиксирована в приказе губернатора и местного совета, а другая (Yallowes) - на первой английской карте. В 1664 г. возникает форма Yellowe, в 1672 г. - Yallowe [Randel, 1960, p. 28]. Современный вариант - Yallahs.

Освещаемый яркими красками спелых абрикосов, пейзаж города Oracabessa вдохновил испанцев на такое образное название (от исп. oro - «золото», cabeza - «голова»). Претерпев графические изменения, ойконим дошел до наших дней в форме Oracabessa. Летопись этого населенного пункта уходит корнями в 1502 г., ко времени прибытия на место Христофора Колумба. В то время этот район был малонаселен индейцами таино. Испанцы создали небольшой пост снабжения под названием Oracabeza для поддержки своих разведочных работ в Карибском бассейне. Он оставался испанским поселением до 1655 г., пока англичане не захватили северное побережье Ямайки. Спустя столетия название Oracabessa фиксируется на карте Ямайки.

Наименование города Porus в округе Манчестер ранее имело название Porras (Поррас), данное ему в честь братьев Порpac (Porras), оказавшихся на острове вместе с Колумбом.
Название города Savannah la Mar восходит к испанскому Sábana de la Mar, что в переводе означает «равнина у моря». Отметим здесь нетрадиционный вариант артикля: la mar вместо el mar используется чаще в поэзии и песенном творчестве, что указывает на мелиоративную коннотацию топонимической единицы.

Наименование поселения Lluidas Vale происходит, по нашему мнению, либо от исп. lucida («блестящий», «прекрасный»), либо от исп. lluvias («дожди»).

Название залива Galina Point является производным от исп. Gallina Punta.

Наименование города Bog Walk в округе Saint Catherine является производным от испанского Boca de Agua.

Происхождение названия города Lacovia определяется по-разному. Согласно одной из версий, Lacovia этимологически связано с испаноязычным ойконимом La Caoban (Доминиканская Республика), поскольку эту территорию Колумб открыл на 2 года раньше, чем Ямайку. По другой версии, изложенной в публикации Э. Лонга, название Lacovia, возможно, произошло от деформированных испанских слов la-agua-via или lago-via и отражает особенности территории, находящейся в низине и обладающей ровным, плоским ландшафтом, в силу чего иногда затопляемой водой из большого болота, окружающего еe [Long, 1774, p. 186-188].

Наименование города Magotty происходит от испанского слова magote, что в переводе означает «связка» или «куча».

Название бухты Cabaritta Punta - от исп. cabra - «коза».

Наименование Negril представляет собой сокращенный вариант от Negrillo - так первоначально назвали поселение испанцы в 1494 году.

Название ойконима Altamont является, как мы предполагаем, сращением исп. alta («высокая») и сокр. montaca («гора»). Наличие французского форманта mont («гора»), на наш взгляд, здесь маловероятно ввиду того, что «высокий» по-французски чаще всего haut, élevé или éminent.

Lucea - производное от Punta Lucía.

Seville - плантация, название которой связано с наименованием первого крупного города на Ямайке, основанного испанцами 
около 1509 г. и бывшего столицей острова на протяжении 23 лет, - Sevilla la Nueva.

\section{2. Несохранившиеся испаноязычные топонимы.}

Единицы этой группы так же неоднородны. Их можно разделить на две подгруппы: названия, утраченные в связи с исчезновением объектов номинации, и испаноязычные названия, замененные на англоязычные.

\section{1. Топонимы, утраченные в связи с} исчезновением объектов номинации. Такие наименования просуществовали на острове всего несколько десятилетий.

Sevilla la Nueva, исп. «новая Севилья». Руины этого города находятся к западу от залива St. Ann's Bay. Sevilla la Nueva основан испанцами в 1510 г. в качестве первой столицы Ямайки. На его месте во время раскопок обнаружено несколько зданий и найдены некоторые свидетельства существования индейской деревни доколумбового периода. В 1554 г. город был разграблен французскими пиратами. Несмотря на то что некоторые люди продолжали там жить, испанцы не восстановили его, а столицу перенесли в другое место. Название Sevilla la Nueva утратилось.

Oristan - одно из ранних испанских поселений, получившее имя по названию муниципалитета Orista (Ориста) в испанской провинции Барселона (по другой версии - по имени города на Сардинии, которая в те времена принадлежала Арагонской короне).

Melilla. Такое наименование раннему испанскому поселению на Ямайке дано по названию испанского города на североафриканском побережье.

Ни Oristan, ни Melilla не сохранились, однако указания на них еще есть на морских картах 1672 и 1688 гг. (см.: [Blome, p. 38; Sloane, p. xvii]).

2.2. Испаноязычные названия, замененные на англоязычные. Переименование географических объектов на Ямайке происходило, по нашему мнению, хаотично: английские завоеватели либо переводили имеющиеся испанские названия, либо заменяли их англоязычными, не соотнося с первоисточником. Приведем примеры.

Bahia Santa Ana. По высадке на Ямайке Колумб дал открытому им острову имя Santa Gloria, которое теперь забыто. Однако второе название острова, Santa Ana, заимствованное у городка в испанской провинции Валенсия, сохранилось в англизированной форме: St. Ann's Bay. Следует отметить, что другой город с испанским названием Santa Gloria существует, он является столицей одного из двенадцати округов, образованных англичанами в 1660 г., - St. Ann.

Villa de la Vega. После событий в Sevilla la Nueva испанская столица острова была перенесена в поселение, расположенное недалеко от южного побережья, где до прихода европейцев проживали индейцы таино. Испанцы назвали столицу Villa de la Vega, а затем переименовали в Santiago de la Vega (St. Jago de la Vega). Английские завоеватели изменили испанское наименование на Spanish Town (англ. «испанский город»).

Port Antonio. Город раньше был испанским поселением Puerto Anton. На различных старых испанских картах значились оба названия.

Port Maria - столица ямайского округа Saint Mary. Первоначально названный Puerto Santa Maria, это был второй город, основанный испанскими поселенцами на Ямайке.

Caguaya. Этот топоним восходит к автохтонному наименованию Cagua, которое дали одному из своих поселений индейцы таино. Испанцы изменили форму топонима на Caguaya и использовали его для большой якорной стоянки, ныне известной как Kingston Harbour. Компонент Caguaya обнаруживается и в наименовании порта Puerto de Caguaya. Это название одно время носила река, которая теперь называется Rio Cobre. Местонахождение города фиксируется на испанских картах XVII в., но британцы случайно перенесли это название в другую точку, изменив его сначала на Cagway, а затем на Port Royal. Тем не менее в актах Тайного совета 1661 г. (АРС) и в Календаре государственных докладов 1661-1668 гг. (Calendar of State Papers) название Cagway сохранялось некоторое время уже после того, как Port Royal официально заменил его: в 1661 г. поселение называли the fort of Cagway, Point Cagway, Point Cagua; как показано В. Рэнделом, на самой ранней известной английской карте, датированной 1661 г., зафиксирована форма Poynt Caggoway [Randel, 1960, p. 26]. 
В эту подгруппу можно включить, кроме уже упомянутых топонимов, наименование гавани Bahía de la Vaca и города Los Angeles, которые сейчас называются Cow Bay и Angels.

\section{Испаноязычные топонимы,}

\section{возникиие в постколониальный период}

Ямайка обрела независимость от Великобритании в 1962 г., однако благозвучие испанского языка и его особая стилистика продолжают вдохновлять жителей острова при создании наименований объектов на микротопонимическом уровне. В данную группу мы определили испаноязычные единицы, появившиеся в период британского господства в регионе и после обретения независимости.

Casa Maria Hotel (дата постройки 1952 г.) гордится тем, что является частью местной истории и культуры страны. Соседние берега когда-то служили популярным пристанищем для пиратов [Интернет-сайт отеля...]. Данная единица - показательный пример добровольного выбора испаноязычных лексем как композитов в современной многокомпонентной урбанонимии Ямайки, несмотря на многолетнее отсутствие испанского политического господства в регионе.

Jose Marti Technical High School была открыта в 1976 г. и носит имя знаменитого кубинского поэта Хосе Марти (1853-1895).

В названиях апартаментов Columbus Heights (функционируют с 2015 г.) и парка Columbus Park содержится имя Колумба. Как видно из приведенных примеров, испаноязычному варианту фамилии Колумба Colyn пока не находится места на карте Ямайки (Columbus - латинский вариант). В данном контексте отметим, что бухта Puerto Seco $B a y$, одна из самых живописных природных гаваней на Карибах, в 1947 г. была переименована в Discovery Bay в память о месте, где, как считается, Христофор Колумб оставил свой первый след на ямайской земле.

\section{Метонимические цепочки}

Вне зависимости от языковой принадлежности, единицы, составляющие топонимический корпус Ямайки, находятся в метонимических отношениях:
- Cabaritta Punta (встречается также в варианте Cabarita (Cabarito) Point), Cabaritta Pint, Cabaritta Island, Cabarita Plantation, Cabaritta River;

- Juan de Bolas River, Juan de Bolas Mountain;

- Negril, North Negril River, South Negril River, Negril Harbour, Negril Hills, Negril Point;

- Cabaritta Punta, Cabaritta River;

- Lucea, Lucea West River, Lucea East

River, Lucea Bridge;

- Montego Bay, Montego River;

- Oracabessa, Oracabessa River;

- Alligator, Alligator Hole River, Alligator Pond, Alligator Pond Bay, Alligator Pond Kay, Alligator Pond River;

- Great Pedro Bay, Rio Pedro, Pedro Valley;

- Yallahs, Yallahs River;

- Morant Point, Morant Bay, Morant River;

- Cedar Grove, Cedar Grove Pen, Cedar Gully, Cedar Valley;

- Lacovia, Lacovia Gut, Lacovia Mountain, Lacovia (Wild Slip) Mountains Liguanea, Liguanea Avenue, Liguanea Mews, Liguanea Pen, Liguanea Plain, Liguanea Plaza, Liguanea Ridge, Liguanea Villa;

- Mosquito Bay, Mosquito Cove, Mosquito Cove Mountain, Mosquito River;

- Mount Diablo, Mount Diablo Gully, Mount Diablo River;

- Pedro, Pedro Cays, Pedro Cross, Pedro Plains, Pedro Point, Pedro Pond, Pedro River, Pedro Valley.

Топонимы-дублеты, по нашим наблюдениям, на острове не зафиксированы, что связано, по-видимому, с небольшой территорией государства и тенденциями в его историческом и политическом развитии.

\section{Выводы}

Во многих регионах мира, подвергшихся колонизации европейцами начиная со времен Колумба, сохранилось значительное количество автохтонных топономинаций. В некоторых странах географические названия, выбранные основателями-колонизаторами, были сохранены после прихода новых колониальных держав. На Ямайке же сохранилось 
мало наименований объектов, данных аборигенами: испанцы уничтожили население таино, и номенклатура региона не свидетельствует об уважении европейских завоевателей к автохтонным географическим именам. При этом лишь четверть от общего количества топонимов составляют испаноязычные номинации. Мы полагаем, что причины отсутствия такой преемственности заключаются в том, что испанское население на Ямайке оставалось немногочисленным вплоть до своего исчезновения, а колонизация вглубь острова происходила крайне медленно.

Лингвопрагматический анализ показал, что новые колонизаторы Ямайки - англичане - не сохраняли испанские топонимические формы, это отражают ойконимы Cagway, WagWater, Yallahs; названия таких крупных городов, как Sevilla, Melilla, Oristan, были утрачены. Большинство сохранившихся до наших дней испаноязычных топонимов на Ямайке зафиксированы на карте или в измененной форме, или в виде англо-испанского гибрида: Negril, Morant, Port Antonio, Bonavista, Mosquito Cove Mountain, Miranda Hill, Clarence Villa Road. Однако в современной урбанонимии региона прослеживается тенденция выбора номинаций, содержащих испаноязычный композит.

Таким образом, гетерогенность ямайских географических наименований и их этимологическая самобытность отражают исторические процессы, повлиявшие на присвоение топонимических номинаций в данном полинациональном регионе Карибского бассейна и Антильского архипелага Нового Света со времен Колумба до наших дней.

\section{СПИСОК ЛИТЕРАТУРЫ}

Биография Куджо. URL: http://www. understandingslavery.com/index.php-option= com_content $\&$ view $=$ category\&layout $=\mathrm{key} \&$ $\mathrm{id}=51$ \&Itemid $=88 \&$ limitstart $=10$.html?option $=$ com content\&view $=$ category \&layout $=\mathrm{key} \&$ $\mathrm{id}=51$ \&Itemid=88\&limitstart=10 (дата обращения: 29.05.2019).

Бушманов А. А., Митчелл П. Д., 2017. Ямайский вариант английского языка в пост-креольском континууме // Вестник Тамбовского университета. Серия: Гуманитарные науки. Т. 22, вып. 2(166). C. 15-19. DOI: 10.20310/1810-02012017-22-2(166)-15-19.

Дридзо А. Д., 1971. Ямайские маруны. М. : Наука. $237 \mathrm{c}$.

Дроздов А. В., 2017. Семантические пути развития заимствований в мезолекте карибского варианта английского языка // Studia Germanica, Romanica et Comparatistica. T. 13, № 3 (37). C. 15-27.

Интернет-сайт отеля CasaMaria. URL: http:// casamariahotel.net/content/about/ (дата обращения: 03.06.2019).

Лесниковская И. В., 2013. Английский ямайский и креольский ямайский: язык или языки? // Вестник Московского государственного областного гуманитарного института. Серия: Филология. Лингвистика и межкультурная коммуникация. T. 1,№ 1.C. 9 .

Мартыненко И. А., 2018. Испаноязычные топонимы США. Тамбов : Юком. 104 с.

Мартыненко И. А., Ильина А. Ю., Куприянова М. Е., 2019. Топонимия Фолклендских островов сквозь призму территориальных споров // Политическая лингвистика. № 2 (74). С. 67-78. DOI: 10.26170/pl19-02-07.

Степанов Ю. С., 1980. Ямайка. М. : Мысль. 167 с.

Тарасова Л. А., 2006. Патуа - язык Ямайки // Латинская Америка. № 1. С. 77-79.

Чеснокова О. С., Мартыненко И. А., 2019. Испаноязычная топонимия Филиппин: структура и прагматика // Acta onomastica. № 2. P. 171-185.

Beek R., 1975. Place Names of Jamaica. Kingston: The University of the West Indies. $178 \mathrm{p}$.

Blome R., 1678. A Description of the island of Jamaica; with the other isles and territories in America, to which the English are related... Published by Richard Blome. Together with the Present state of Algiers. L. : Printed by T. Milbourne. 88 p.

CassidyF. G., 1988. The Earliest Placenames in Jamaica // Names. Vol. 36. P. 151-161.

Cundall F., 1909. Jamaica Place-Names. Kingston : Institute of Jamaica. $24 \mathrm{p}$.

Cundall F., Pietersz J., 1919. Jamaica Under the Spaniards. Kingston : Institute of Jamaica. 115 p.

Higman B. W., Hudson B. J., 2009. Jamaican Place Names. Kingston : University of the West Indies Press. $319 \mathrm{p}$.

Long E., 1774. The History of Jamaica: or, A General Survey of the Antient and Modern State of that Island, with Reflections on its Situation, Settlements, Inhabitants, Climate, Products, Commerce, Laws, and Government. L. : T. Lowndes. $635 \mathrm{p}$.

Padrón F. M., 1952. Jamaica Espacola. Sevilla: Publicaciones de la Escuela de Estudios Hispano-Americanos. xxx, 495 p. 
Padrón F. M., 2003. Spanish Jamaica / transl. from the original Spanish by P. E. Bryan in collaboration with M. J. Gronow and F. O. Moral. Kingston ; Miami : Ian Randle. 376 p.

Randel W., 1960. Survival of Pre-English Place Names in Jamaica // Names. Vol. 8. P. 24-29.

Sand A., 1999. Linguistic Variation in Jamaica. A Corpus-Based Study of Radio and Newspaper Usage. Tübingen : Narr. 197 p.

Sibley K. I., 1978. Dictionary of Place - Names in Jamaica. Kingston : Institute of Jamaica. 184 p.

Sloane H., 1707. A Voyage to the islands Madera, Barbados, Nieves, S. Christophers and Jamaica. In 2 vols. Vol. 1. L. : Printed by B.M. for the author. xlix, 264 p.

\section{ИСТОЧНИКИ И СЛОВАРИ}

БРЭ - Ямайка // Большая российская энциклопедия. URL: https://bigenc.ru/geography/text/ 4926106 (дата обращения: 16.07.2019).

$A P C$ - Acts of the Privy Council, I, 159, entry \# 511 dated 29 April 1661.

Calendar of State Papers - Calendar of State Papers, Colonial Series. Vol. 2, 1661-1668 (London, 1880), p. 5, letter sent by governor D’Oyley. 850 p.

$D R A E$ - Diccionario online de Real Academia Espacola. URL: https://dle.rae.es/?id=907i46j (date of access: 07.08.2019).

\section{REFERENCES}

Biografiya Kudzho [Cudjoe's biography]. URL: http:// www.understandingslavery.com/index.phpoption $=$ com content\&view $=$ category\&layout $=$ key\&id $=51 \&$ Itemid $=88 \&$ limitstart $=10$. html ? option $=$ com content $\&$ view $=$ category\&layout $=$ key\&id $=51 \&$ Itemid $=88 \&$ limitstart $=10 \mathrm{https}: / /$ bigenc.ru/geography/text/4926106 (accessed 29 May 2019).

Bushmanov A.A., Mitchell P.D., 2017. Yamayskiy variant angliyskogo yazyka $\mathrm{v}$ post-kreolskom kontinuume [The Jamaican variant of English language in the post-creole continuum]. Vestnik Tambovskogo universiteta. Seriya Gumanitarnye nauki [Tambov university review: Series humanities], vol. 22, iss. 2 (166), pp. 15-19. DOI: 10.20310/1810-0201-2017-222(166)-15-19.

Dridzo A.D., 1971. Yamayskie maruny [Jamaican Maroons]. Moscow, Nauka Publ. 237 p.

Drozdov A.V., 2017. Semanticheskie puti razvitiya zaimstvovaniy v mezolekte karibskogo varianta angliyskogo yazyka [Semantic development of borrowing in the Caribbean English mesolect]. Studia Germanica, Romanica et Comparatistica, vol. 13, no. 3 (37), pp. 15-27.

Internet-sayt otelya CasaMaria [Website of the hotel Casa Maria]. URL: http://casamariahotel.net/ content/about/ (accessed 03 June 2019).

Lesnikovskaya I.V., 2013. Angliyskiyyamayskiy i kreol'skiy yamayskiy: yazyk ili yazyki? [English Jamaican and Jamaican Creole: the language or languages?]. Vestnik Moskovskogo gosudarstvennogo oblastnogo gumanitarnogo instituta. Seriya: Filologiya. Lingvistika i mezhkulturnaya kommunikatsiya, vol. 1, no. 1, p. 9.

Martynenko I.A., 2018. Ispanoyazychnye toponimy SshA [Spanish-language place names in the United States]. Tambov, Yukom. 104 p.

Martynenko I.A., Ilina A.Yu., Kupriyanova M.E., 2019. Toponimiya Folklendskikh ostrovov skvoz prizmu territorialnykh sporov [Falkland Islands toponymy through the prism of territorial disputes]. Politicheskaya lingvistika [Political Linguistics], no. 2 (74), pp. 67-78. DOI: 10.26170/ pl19-02-07.

Stepanov Yu.S., 1980. Yamayka [Jamaica] Moscow, Mysl' Publ. 167 p.

Tarasova L. A., 2006. Patua-yazyk Yamayki [Patua is a language of Jamaica]. Latinskaya Amerika, no. 1, pp. 77-79.

Chesnokova O.S., Martynenko I.A., 2019. Ispanoyazychnaya toponimiya Filippin: struktura i pragmatika [Spanish toponymy in the Philippines: structure and pragmatics]. Acta onomastica, no. 2, pp. 171-185.

Beek R., 1975. Place Names of Jamaica. Kingston, The University of the West Indies. $178 \mathrm{p}$.

Cassidy F.G., 1988. The Earliest Placenames in Jamaica. Names, vol. 36, pp. 151-161.

Cundall F., 1909. Jamaica Place-Names. Kingston: Institute of Jamaica. $24 \mathrm{p}$.

Cundall F., Pietersz J., 1919. Jamaica Under the Spaniards. Kingston: Institute of Jamaica. $115 \mathrm{p}$.

Higman B.W., Hudson B.J., 2009. Jamaican Place Names. Kingstoná University of the West Indies Press. 319 p.

Long E., 1774. The History of Jamaica, or, A General Survey of the Antient and Modern State of that Island, with Reflections on its Situation, Settlements, Inhabitants, Climate, Products, Commerce, Laws, and Government. London, T. Lowndes. 635 p.

Padrón F.M., 1952. Jamaica Espacola [Spanish Jamaica]. Sevilla: Publicaciones de la Escuela de Estudios Hispano-Americanos. xxx, 495 p.

Padrón F. M., 2003. Spanish Jamaica. Translated from the original Spanish by Patrick E. Bryan 
И.А. Мартыненко. Испаноязычная топонимия Ямайки: диахронический аспект

in collaboration with Michael J. Gronow and Felix Oviedo Moral. Kingston; Miami, Ian Randle. 376 p.

Randel W., 1960. Survival of Pre-English Place Names in Jamaica. Names, vol. 8, pp. 24-29.

Sand A., 1999. Linguistic Variation in Jamaica. A Corpus-Based Study of Radio and Newspaper Usage. Tübingen, Narr. 197 p.

Sibley K.I., 1978. Dictionary of Place - Names in Jamaica. Kingston, Institute of Jamaica. 184 p.

Sloane H. A Voyage to the islands Madera, Barbados, Nieves, S. Christophers and Jamaica. In 2 vol. London: Printed by B.M. for the author, 1707. vol. I. xlix, $264 \mathrm{p}$.

\section{SOURCES AND DICTIONARIES}

Yamayka [Jamaica]. Bolshaya Rossiyskaya entsiklopediya [Great Russian encyclopedia]. URL: https://bigenc.ru/geography/text/4926106 (accessed 16 July 2019).

Acts of the Privy Council, I, 159, entry \# 511 dated 29 April 1661

Calendar of State Papers, Colonial Series, vol. 2, 16611668 (London, 1880), p. 5, letter sent by governor D’Oyley. 850 p.

Diccionario online de Real Academia Espacola [Royal Spanish Academy online dictionary]. URL: https: //dle.rae.es/?id=907i46j (accessed 07 August 2019).

\section{Information About the Author}

Irina A. Martynenko, Candidate of Sciences (Philology), Associate Professor, English Language Department, Kutafin Moscow State Law University (MSAL), Sadovaya-Kudrinskaya St, 9, 125993 Moscow, Russia, irineta@rambler.ru, https://orcid.org/0000-0002-9798-3378

\section{Информация об авторе}

Ирина Анатольевна Мартыненко, кандидат филологических наук, доцент кафедры английского языка, Московский государственный юридический университет им. О.Е. Кутафина (МГЮА), ул. Садовая-Кудринская, 9, 125993 г. Москва, Россия, irineta@rambler.ru, https://orcid.org/0000-0002-9798-3378 